\title{
Participatory Research in EE: Some issues of epistemology and methodology
}

\author{
Ian Robottom ${ }^{1}$ \\ Faculty of Education Deakin University - Australia
}

resumo $O$ tema da conferência sobre epistemologia e metodologia sugere um interesse nas questões epistemológicas da pesquisa em Educação Ambiental (EA). Eu já defendi anteriormente que por muito tempo pareceu haver uma cegueira na pesquisa em EA: havia um pressuposto não fundamentado de que toda pesquisa em EA era e deveria ser conduzida sob a perspectiva conceitual das ciências aplicadas, que não reconhecia ou problematizava os pressupostos epistemológicos da pesquisa. Neste trabalho, pretendo discutir a questão da coerência epistemológica entre os conteúdos substantivos da EA, por um lado, e a metodologia de pesquisa, por outro. O trabalho apresentará dois projetos internacionais recentes de EA para explorar questões referentes à natureza, estágio e papel da pesquisa em EA. Algumas características do desenvolvimento de projetos ambientais comunitários em dois locais distintos serão descritas, ilustrando a complexidade e a contextualização das questões ambientais como conteúdos para a EA. As implicações para a pesquisa que busca reconhecer e respeitar as relações com contextos comunitários serão consideradas quanto às seguintes questões: De quem é a agenda de pesquisa? Qual a importância das preconcepções dos participantes e parceiros dos projetos sobre a natureza da pesquisa? O que é rigor na pesquisa participante em EA?

palavras-chave Educação Ambiental, epistemologia, pesquisa

abstract The conference theme of epistemology and methodology suggests an interest in epistemological issues in environmental education research. I have argued

1 ian.robottom@deakin.edu.au. 
previously that for too long there seemed to be a blindness in environmental education research: that there was an unwarranted assumption that all research in environmental education was and should be conducted within an applied science conceptual framework that did not recognise nor problematise the epistemological assumptions of research. In this paper I intend to address the issue of epistemological coherence between the substantive subject matters of environmental education on the one hand and research methodology on the other. The paper will draw upon two recent international environmental education projects to explore issues concerning the nature, status and role of research in environmental education. A number of features of community-based environment development projects in two different settings will be described, illustrating the complexity and contextuality of environmental issues as subject matters for environmental education. The implications for research that seeks to acknowledge and respect relationships within community contexts will be considered in relation to the following questions: Whose research agenda? The importance of project partnerships Participants' preconceptions about the nature of research. What is 'rigor' in participatory research in environmental education?

key words Environmental education, epistemology, research

\section{Introduction}

The conference theme of epistemology and methodology suggests an interest in epistemological issues in environmental education research. I have argued previously that for too long there seemed to be a blindness in environmental education research: that there was an unwarranted assumption that all research in environmental education was and should be conducted within an applied science conceptual framework that did not recognise nor problematise the epistemological assumptions of research. In this paper I intend to address the issue of epistemological coherence between the substantive subject matters of environmental education on the one hand and research methodology on the other. 


\section{A perspective on environmental issues as common subject matter in environmental education}

A justification for taking some time to present a perspective on the nature of environmental issues is the observation that much distinctive environmental education consists in the educational exploration of environmental issues. Environmental education curriculum often takes the form of investigations, by teachers and students, of contested proposals for local environmental change (Greenall Gough \& Robottom, 1993). For example, at the level of state government in Australia, the Victorian Ministry of Education's (1990) Environmental Education Policy (MOE, 1990) offers further support for a kind of environmental education work that explores real environmental issues, recognises values and is socially critical in perspective, suggesting that curriculum approaches to environmental education should have the following characteristics:

- they should be based on real problems;

- they should clarify values;

- they should make use of both ecological and interdisciplinary skills and concepts;

- they should be socially critical;

- they should be action orientated;

- they should encourage the development of a sustainable environment;

- they should involve students working together in groups ( $p$. 83).

I will draw on two recent international research and development projects in order to illustrate some expressions of 'environmental issues' in order to prepare the way for a consideration of the capacity of educational research to engage issues such as these as subject matters.

Both projects were based on participatory processes involving local communities in developing case studies of aspects of their own 
environment as perceived and constructed jointly by research partners. How do projects such as these illuminate the notion of "environmental issues' in environmental education? What I intend to do here is begin by listing a sample of the environmental topics that the two projects have addressed in their day-to-day activities, and then identifying some of the common characteristics of environmental issues in general. Further insight into the nature of these issues may be gained through reference to the project publications cited below.

\section{AusLinks Project}

This project was conducted in the late 90's in South Africa, and provides some insight into local environmental education projects in that country at the time when it was redefining its educational organisation in the post-apartheid era (Robottom \& Kyburz-Graber, 2000), (LeGrange, Makou, Neluvhalani, Reddy, \& Robottom, 1999).

The participating institutions all developed case studies on teacher networking in environmental education and issues-based curriculum development at tertiary level. A feature of these case studies is their diversity and contextuality. In summary, some of the environmental issues addressed by participants in this project were:

-Investigating the relationship of informal trading (street-vending) and garbage accumulation in local shopping centres;

-Development of a new curriculum focussing on the sensitive issue of an HIV/AIDS epidemic in a local mining town;

-Using a issues-based approach (involving water pollution of local waterways) to environmental education to encourage teacherinitiated curriculum development within post-apartheid South Africa; and

-The development of local networks of environmental educators within the context of a formerly bureaucratic structure, with a view to changing historically imposed structures, relationships and practices in post-apartheid South Africa. 


\section{Cooperation and Development in Sparsely Populated Areas (CADISPA)}

The CADISPA project is based in the Department of Community Education in the Faculty of Education at the University of Strathclyde in Glasgow, Scotland. The project is currently coordinated by Geoff Fagan (CADISPA, 2001) of the Department of Community Education. According to a recent (December 2001) brochure on the CADISPA project, CADISPA is concerned with developing a definition of sustainability that will be of help to local people and to the economic community. There is a clear participatory, power sharing interest expressed in the comment that "people are central to the identification and prioritisation of their own local agenda. It is they who prioritise and decide on their own local development". Thus CADISPA is linked with (draws from and potentially makes a contribution to) the enduring environmental education discourses of community, environmental issues, and participatory approaches, and to the literature that critically appraises these discourses.

This project has a long history in the United Kingdom, and my involvement was only a short and recent one (in the second half of 2002). However I was able to visit a number of eco-development projects in sites in the highlands and islands and develop some 'vignettes' of these activities, later published by the University of Strathclyde(Robottom, 2003). In brief, recent CADISPA activities focused on such local initiatives as:

-re-development of a community hall as infrastructure supporting community functions and economic activity (largely tourism) within a context characterised by the perhaps competing values of respect for isolation and peace and quiet;

-development of a croft house and visitors' centre on isolated Lismore Island;

-road linkage between communities at the north and south ends of a sparsely populated island; 
-attempted re-development of a community hall for a number of small-scale income generating activities and functions within a context of a range of competing proposals for use of the structure;

- further development of a drop-in centre providing support for local people with mental health issues;

-re-development of a waterfront area with a view to ensuring continuation of a ferry service essential to local tourist trade.

In most of these eco-development projects in remote and sparsely populated areas, there was an implicit or explicit tension between an interest in ensuring economic sustainability and an interest in environmental and social sustainability.

So, what can we conclude about the nature of environmental issues from this sample? Firstly, it seems clear that any issue (environmental or otherwise) is constituted of differing opinions held by human beings. According to The Macquarie Dictionary of 1981, an issue is 'a point in question or dispute, as between contending parties in an action at law', and 'a point or matter the decision of which is of special or public importance'. In these definitions, the 'contending parties' who dispute the point and who imbue it with special or public importance' are parties of human beings. Hence an environmental event (or proposal relating to such an event) only becomes an issue when it is in contention and when its resolution is judged by humans to be of importance. An environmental issue is therefore a human or social construct -- it does not exist independently of human consciousness and it is not something possessing an independent ontological existence.

Secondly, it is clear that environmental issues are highly contextual. The meaning and significance of an environmental issue -what is perceived as being of special or public importance -- will tend to vary in time and space. The meaning and significance of a given environmental issue will be judged to be lesser or greater at some times in history and in some locations than in others.

Another characteristic of environmental issues is their multidimensionality. While it is true that most environmental issues have a 
strong scientific dimension (at least in so far as construing environmental issues from an ecological perspective is 'scientific'), and while it seems also to be true that for many environmental educators the scientific dimension is the most important, most environmental issues also have identifiable social, cultural, political and historical dimensions.

In summary, then, analysis of these two projects and some of the relevant literature suggests that environmental issues are characterised by he following features:

-they are complex in their structure;

-they are contextual in the way they express themselves;

-they involve a wide range of stakeholders;

-these stakeholders express a wide range of values and interests;

-a politicised perspective is a necessary component in their resolution;

-their resolution requires negotiation and reconciliation, and these are usually difficult processes;

-the process of their resolution is a function of social, cultural, political and environmental elements, and is often a case of 'cultural survival'; and

-above all, environmental issues are socially constructed and need to be recognised and treated as such.

That an environmental issue is essentially a human or social construct with social as well as scientific dimensions has implications for environmental education as a form of education that seeks to base its curriculum on an investigation of such issues, and for research that seeks to inform such an approach to education. One implication is that to approach environmental education solely or even largely from a scientific perspective (as a kind of science education), rather than placing environmental education within a social discourse, is to risk an inadequate if not distorted educational exploration of the issue in question (Robottom, 1983): 
The positivistic world-view promulgated in conventional science education disregards the important qualitative dimensions of that majority of environmental issues which involve "quality of life" or "social need" concerns - emotions, beliefs, aspirations, aesthetics, and perhaps most important of all, political factors. It could be argued that a view of environmental issue resolution which stresses the role of technical "machinery" (the processes of an objective scientific method) in dealing with environmental issues succeeds in creating a false impression of the way in which these issues are resolved, by masking such value-laden political machinations as negotiation, manoeuvring, persuasion, the offer of inducements, the exertion of influence, and so on (p. 29).

What are the implications for research of this argument that environmental issues possess, in addition to a scientific dimension, identifiable social, cultural, political and historical dimensions?

\section{A Perspective on Research in Environmental Education}

There is now available a much greater range of approved approaches to research in this field than was the case in the 70s and 80 s. These approaches are variable in terms of their accessibility to the practitioner to support and mediate his or her professional selfdevelopment. Some are empirical and some are not. Some are statistics-based and some are not. Some are best conducted by outside research 'experts' and some are not. In a sense, environmental education research in the last ten years has escaped a solely scientific discourse and to a greater extent is now located within a social discourse that coheres, I would argue, more readily with the nature of environmental issues as described above, and therefore with the characteristics of environmental education curriculum.

I would assert that participatory, praxis-based approaches to research in environmental education -- those which are directly concerned with a reflective interaction between personal professional theory, personal professional practice, and the professional and social 
settings within which these are located - appear to have the most coherence with other dimensions of environmental education. Because they implicate biography, practice and the professional and social settings within which practices take place, they are essentially contextual, a characteristic which resonates with the diversity and contextuality of curriculum grounded in an exploration of local environmental issues.

There are many ways in which a commitment to praxis-based approaches to research can be expressed. This is evident in the range of approaches adopted by recent projects, including the those outlined earlier in this presentation. For example, in the AusLinks project, instead of following a single defined research procedure, we sought to simply work flexibly within a set of broad research principles. These principles were that research should be:

- contextual: that the research respect and relate closely to the particular workplaces and workplace issues of participants;

- responsive: that the issues explored in the research processes are those of interest and concern to participants themselves;

- emergent: that the knowledge that carries most weight in discussions about how to improve practice is that which emerges from research conducted by participants themselves;

- participatory: that participants are involved directly and as equitably as possible in all dimensions of the research process (for example: identifying issues to be addressed; collection and analysis of case study data; development and dissemination of materials and reports);

- critical: that the processes of research look beyond the surface layers of activity at the levels of policy, organisation and practice to identify and appraise the values, assumptions and interests that inform and justify this activity;

- praxiological: that processes of research proceed through and are mediated by praxis -- the conscious and continuous interplay between theoretical and practical considerations. 
As we have found in the projects cited earlier, in praxis-based research the appropriate starting point is always the issues of interest and concern to participants themselves - it is important that participants be provided with opportunities to engage in the generation of culturallyderived knowledge through inquiries into environmental and environmental education issues perceived as being meaningful and significant in their own personal, professional and environmental contexts.

\section{Issues in the Conduct of Participatory Research}

Of course, it is much easier to make a case for participatory research in environmental education than it is to actually do something worthwhile in the name of such research. Nothing is easy in participatory project research; in part, it is a matter of balancing opportunities and constraints while operating flexibly within a set of guiding principles based on certain epistemological, ontological and ideological assumptions which themselves need to be subject to continuing appraisal. In this section I intend to reflect on the experiences of these projects and to present some of the issues I have found to be associated with participatory, collaborative research (see also (Robottom \& Sauve, 2003)).

\section{Whose research agenda?}

One of the distinctive features of participatory research is its focus on issues of interest and concern to participants themselves. Perhaps unlike some other forms of educational research whose claims for rigor depend in part on conscious attempts to retain a de-politicised perspective in the operations of the research, participatory research is unavoidably political and necessarily politicised. Participatory research proffers itself as an agency for 'inside' project participants to address existing power relationships that may be perceived as inequitable in one sense or another. Participatory research has an interest in internalising the locus of control over the research agenda by encouraging participants to direct the research towards issues of 
interest and concern to themselves (Hart, Robottom, \& Taylor, 1994). A relevant methodological question concerns how to ensure a focusing of the research on issues of interest and concern to participants - issues which have meaning within particular social, environmental, cultural and educational contexts. The methodological issue for participatory research is to find ways to ensure that this happens.

\section{The importance of project partnerships}

Most of the examples of participatory research I have been associated with have been collaborative in nature. They have been collaborative in the sense of involving a collective of people in as many different aspects of the research as possible, partly as an alternative to the more usual division of labor that occurs in research (where 'researchers' are disjoined from the 'subjects-as-objects' of research), and partly because group reflection on practice can be more powerful than individual reflection (Robottom, 1987) and has a greater potential for production of contextually relevant knowledge. And in each of the projects described earlier, the collaborative work engaged in during the project continued beyond the life of the project itself. Networks of colleagues established during the project have, to some extent, attained a life of their own that has continued to serve project participants well in both intellectual and political terms.

\section{Participants' preconceptions about the nature of research}

Participatory research by definition involves the collaboration of research partners in as many of the phases of research as possible. However, different participants come from different backgrounds - for example participants in the community-based projects come from a community development background rather than from a formal educational research background. In our experience, it can never be assumed that participants come to the project with a common 'default' construction of what counts as research in environmental education. Some participants approach a project with the expectation that the 
research is of an 'accountability exercise' kind, in which universitybased researchers seek to measure the achievements of other participants against a set of independently-existing and externally-derived set of criteria. Many assume that the very word 'research' entails the employment of quantitative applied-science research designs. It has been important to recognise these prior assumptions about the nature of research and to engage them directly very early on in project discussions, and for the evolving methodology-in-action to be the subject of open and continuing negotiation. This is one of the reasons why it usually takes time to build a research culture within any new project community.

\section{What is 'rigor' in participatory research in environmental education?}

In 2002, members of the University of Quebec at Montreal's (UQAM's) Centre for Environmental Education Research engaged in a seminar on the topic of rigor in environmental education research. The approach was simply to reflect on how 'rigor' was constructed in the various research projects engaged in by Centre participants - that is to start with the concrete research practice gained in the ten or so projects currently underway within the Centre in proffering ideas about the topic of rigor in environmental education research. Some of the perspectives advanced were:

-Standard dictionary definitions refer to such qualities as severity, strictness, harshness, fixity, hardness. Such standard definitions seem to reflect characteristics of quantitative research rather than those of the now broad range of research approaches;

-Integrity, honesty and humility on the part of the researcher are part of what it is to be rigorous;

- Above the a priori quality of any particular research design, rigor calls a posteriori for methodological transparency (relating what really happened) and acknowledgement of the inherent and externally-imposed limits of the research. 
-It is important to negotiate the research agenda with project participants;

-Ethics is essential part of rigor. In participatory research, to be ethical in part means to conduct research that is relevant to participants, to make sure results are collectively discussed and interpreted with participants, and to share with participants the act of research communication and diffusion, so as they are recognized as full actors of the research process and of the production of knowledge.

-Self-reflection of the practice of research is a component of rigor;

-Processes of iterative synthesis of research accounts add to the rigor of research;

-Processes of collaborative self-evaluation contribute to rigor;

-A questioning of the dominant discourse is an element of a rigorous approach.

-Internal coherence among the philosophical assumptions (epistemological, ontological, ideological...) underpinning the research is another element of rigor in research;

-It is possible that the concept of 'rigor' is fatally flawed through its historical construction within an applied science conceptual framework and that in fact we should be using a different term altogether to qualify desired characteristics of participatory research.

It is clear that continued careful reflection on the meaning of rigor, or an alternative notion for appraising the quality of research, is required in the field of qualitative approaches to environmental education research, particularly participatory environmental education research.

\section{Conclusion}

In this presentation I have attempted to draw together some observations made during involvement in two recent national and international projects in environmental education. I have argued that 
environmental issues - frequently the subject matter of environmental education curriculum - are essentially social constructs whose meaning and significance are a function of the geographical and social settings within which they are played out. To the extent that environmental education curriculum is issues-based it entails being 'socially critical' about 'real problems' in the community (MOE, 1990), and because environmental education curriculum exhibits these characteristics, I have argued that an adequate form of professional development should also be contextual, localised, and respectful of emerging knowledge. I have also argued that a coherent approach to educational research will be one that is sensitive to the need for contextuality, is accessible for practitioners, and which (by virtue of its praxiological nature) deals in emerging community-based knowledge. Finally I have introduced some practical issues in the actual conduct of participatory research.

\section{References}

CADISPA. (2001). C.A.D.I.S.P.A. In G. Fagan (Ed.). Glasgow: University of Strathclyde.

GREENALl GOUGH, A., \& ROBOTTOM, I. (1993). Towards a Socially Critical Environmental Education: Water quality studies in a coastal school. Journal of Curriculum Studies, 25(4), 301-316.

HART, P., ROBOTTOM, I., \& TAYLOR, M. (1994). Dilemmas in Participatory Enquiry: A case study of method-in-action. Assessment \& Evaluation in Higher Education, 19(3), 201-214.

LEGRANGE, L., MAKOU, T., NELUVHALANI, E., REDDY, C., \& ROBOTTOM, I. (1999). Professional Self-Development in Environmental Education: the case of the 'Educating for Socio-Ecological Change Project'. Unpublished manuscript, Grahamstown, South Africa.

MOE. (1990). Ministerial Policy for Environmental Education. Melbourne, Victoria: Ministry of Education.

ROBOTTOM, I. (1983). Science: A Limited Vehicle for Environmental Education?" Australian Science Teachers Journal. 29, 1(27-31). 
(1987). Two Paradigms of Professional Development in Environmental Education. The Environmentalist, 7(4), 291-298.

(2003). Helping People Help Themselves: CADISPA Review Report. Glasgow: The University of Glasgow.

\& Kyburz-Graber, R. (2000). Recent International Developments in Professional Development in Environmental Education: Reflections and Issues. Canadian Journal of Environmental Education, 5, 1-19.

\& Sauve, L. (2003). Reflecting on Participatory Research in Environmental Education: Some issues for methodology. Canadian Journal of Environmental Education, 8((in press)). 